\title{
Erratum to monitored transoral endoscopic thyroidectomy
}

doi: 10.21037 /gs.2019.10.09

View this article at: http://dx.doi.org/10.21037/gs.2019.10.09

Erratum to: Gland Surg 2019;8:318-21

Monitored transoral endoscopic thyroidectomy

In the August 2019 issue of Gland Surgery, the article entitled "Monitored transoral endoscopic thyroidectomy" (1) was published with an error when retrieving in PubMed.

One of the author's name Pietro Giorgio Calò is written as Giorgio Calò P which is in wrong sequence when retrieving this article in PubMed. It should be written in Calò PG instead of Giorgio Calò P when retrieving in PubMed.

The publisher regrets the error and is sorry for the inconvenience caused.

\section{References}

1. Calò PG, Medas F, Canu GL, et al. Monitored transoral endoscopic thyroidectomy. Gland Surg 2019;8:318-21.

Cite this article as: Editor Team. Erratum to monitored transoral endoscopic thyroidectomy. Gland Surg 2019;8(5):588. doi: 10.21037/gs.2019.10.09 